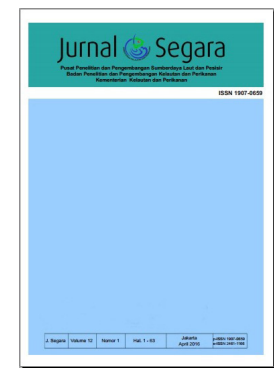

JURNAL SEGARA

http://ejournal-balitbang.kkp.go.id/index.php/segara

ISSN : 1907-0659

e-ISSN : 2461-1166

Nomor Akreditasi: 766/AU3/P2MI-LIPI/10/2016

\title{
ASSESSING MANDEH REGION AS THE CENTER OF MARINE ECOTOURISM IN WEST SUMATRA PROVINCE, INDONESIA: MASS TOURISM ISSUE AND VULNERABILITY ASPECTS
}

\author{
Ulung J. Wisha',2), Try Al Tanto'), Nia Naelul Hasanah Ridwan ${ }^{1)}$, Guntur A. Rahmawan ${ }^{1,3)}$ \\ Ruzana Dhiauddin'1), Koko Ondara1), \& Wisnu A. Gemilang1)

\begin{abstract}
${ }^{1)}$ Research Institute for Coastal Resources and Vulnerability, Ministry of Marine Affairs and Fisheries, Indonesia
2)Physical Oceanography Laboratory, Faculty of Science, University of the Ryukyus, Japan

3)Department of Water and Coastal Resources Management, Bung Hatta University, Indonesia

JI. Raya Padang-Painan KM 16, Komp. PPS Bungus, Padang 25245 Indonesia
\end{abstract}

Received: 12 November 2020; Revised: 26 November 2021; Accepted: 28 November 2021

\begin{abstract}
Nowadays, Mandeh Region has developed significantly as the center of marine ecotourism in West Sumatra Province. Many local and international tourists were visiting this site. Due to those conditions, many threats emerged, such as mass tourism evoking damages and pollutions. This study aimed to examine the feasibility of the Mandeh Region for tourism activity and identify the impacts of mass tourism. A direct survey has been conducted. We assessed water quality, accessibility, and social conflicts using a scoring method. A modified matrix categorizing some parameters as the underlying data for marine tourism sustainability was used. We also developed Smartline and CVI model to assess the vulnerability level along Mandeh coastal bay. Local zonation was recommended to reduce more environmental damages. We examined the feasibility of the Mandeh region as a place for ecotourism that reached $72.46 \%$, indicating this area is sufficiently feasible. The absence of local regulations before the Mandeh Region was established as the center of marine ecotourism resulted in mass tourism phenomena that elevated marine litter accumulation. Moreover, many resorts near the coast have recently played a role in triggering pollution and damage. Advanced regulation and management are necessary to diminish negative impacts on both the environment and society.
\end{abstract}

Keywords : Marine ecotourism, Mandeh region, mass tourism, environmental damages.

Corresponding author:

Jl. Pasir Putih I Ancol Timur, Jakarta Utara 14430. Email: ulungjantama@gmail.com 


\section{INTRODUCTION}

Pesisir Selatan Regency is one of the westernmost coastline cities in Sumatra. This region has been famous recently because of its successful ecotourism development (Mukhtar et al., 2016). Mandeh is the area of significance in the Pesisir Selatan Regency. Many natural attractions exist, such as marine ecotourism, cultural heritages, diving sites, and the magnificent view from the hilly slopes (Gemilang et al., 2020). However, this region is also vulnerable to earthquakes, landslides, and other coastal hazards because it is positioned between the subduction zone and mountainous area and directly bordered by the Indian Ocean (Santoso et al., 2011).

"The paradise in the south" is an epithet given for Mandeh coastal bay, well-known for its underwater beauty. Nowadays, this region has become the center for marine and fisheries activities. Marine and heritage ecotourism is the main program promoted by the local and central government. The successful development of tourism in the Mandeh region has made this area free from the title of the most impoverished region in West Sumatra. However, this status is not gone well; many impacts on the environment and social issues are currently revealed (Dillenia \& Arief Troa, 2016).

Due to the substantial potency of the Mandeh region as a tourism area, land dispute problems occurred. Locals also reported that the accumulation of coastal debris in the tourism area increased significantly. Pressures to the coastal area also commenced raising the vulnerability level within the vital area. Ecosystem damages such as regional coral bleaching, water quality degradation, algal blooming, etc., have taken place within Mandeh coastal bay due to mass tourism and rapid urban development. Moreover, the presence of many new resorts along the Mandeh coastline contributes to dramatic land-use change. Nowadays, the complex issue faced by local government is how to control mass tourism and diminish the environmental problems (Holladay et al., 2018).

An assessment of the ecotourism aspect is essential to create a possible solution recommended to the local and central government. The mass tourism issue must be overcome and the vulnerability aspect in the tourism area. A previous study (Syam, 2017) arranged the strategy to organize mass tourism and reduce ecological damage. Also, (Gemilang et al., 2020) defined that Mandeh Bay is moderately prone to coastal hazards, and the tourism area needs to be managed for sustainable environmental resilience. In contrast, this study will reveal the feasibility level of Mandeh coastal bay as the center of the ecotourism region in West Sumatra through scoring and spatial method. In this study, we assessed the feasibility of marine tourism by modifying the matrix of the marine tourism feasibility index previously developed by Tanto et al. (2017) and Arlius et al. (2017). Moreover, GISbased approaches are also used to support the impact of mass tourism in the Mandeh Region. Thus, this study aims to assess the vulnerability level and the feasibility of the Mandeh tourism area and initiate future policy and management to overcome the environmental issue.

\section{METHODOLOGY}

\section{Study Site}

Administratively, Mandeh Region is located around Carocok Village, Koto IX Tarusan Sub-District, Pesisir Selatan Regency. The development in tourism in Mandeh had directed as the object of marine ecotourism since 2002. The increase in urban development and the number of tourists occurred after establishing this area as the national tourism region. During the last five years, especially in 2013-2014, the increase in the frequency and the number of tourists in the Mandeh Region occurred. It was dominated by the domestic tourist of $80 \%$ and $5 \%$ for the international visitor (Mukhtar et al., 2016).

Socio-economically, most of the society in Mandeh Bay are fishers. Marine and fisheries potencies are significant, but only $35 \%$ have been exploited. Capture fisheries production reached approximately $25,575.21$ tons in 2008 , with the number of fishers around 18,775 people. The aquaculture sector is also productive, with around 103.6 tons within 1,792 hectares area (Wisha et al., 2018).

The area of the coral reef ecosystem is approximately 521.57 hectares scattered along the coastal region. Unfortunately, around $85.25 \%$ of the coral reef ecosystem has been damaged. The dense coral cover is found in Cingkuak and Penyu Island. Mangrove forest area reaching 622.82 hectares is scattered in all protected coastal regions. The highest mangrove cover is located in Koto Xi Tarusan SubDistrict with around 37.3 \% (Wisha et al., 2018).

Mandeh Bay is included in the area prone to hazards and disasters in the form of earthquakes, floods, landslides, wave overtopping, and tsunami (Hermon, 2016). It is induced by this region's strategic position, which is positioned within the confluence of continental plates. The land-use changes have contributed to raising the vulnerability level of Mandeh coastal bay. So far, coastal hazards have become obstacles in the regional development efforts for elevating public welfare.

With the increase of tourism visits, the local 
government has promoted many underwater tourism objects such as the iconic MV Boelongan Netherland shipwreck, well-known as the most visited diving site in Mandeh Bay. In 2008, it was recorded that as many as 88,458 tourists visited the Mandeh ecotourism area with around 201 people from overseas, and the rest 88,257 people were domestic. The increase rate in the tourism sector is $16 \%$ per year. (Wisha et al., 2018).

\section{The Assessment of Marine Ecotourism}

As mentioned above, the icon in Mandeh Bay is the MV Boelongan Shipwreck site. In this case, we will assess the feasibility of this site as a diving site using a matrix to evaluate the ecotourism parameters shown in Table 1, and the supporting parameter is shown in Table 2.
To complete the data above, we conducted a field survey in 2019, including a water quality and oceanography survey, site diving using SCUBA, distributing a questioner, and collecting secondary data from the local government, such as the number of tourist visits in Mandeh Region. We assessed the four main sites within Mandeh bay (MV Boelongan Shipwreck Site, Sironjong Island, Sutan Island, and Cubadak Island.

\section{Spatial Analysis; Land-use Changes, Regional Zonation, And Coastal Vulnerability Index}

We analyzed the land-use changes by comparing two different periods of a satellite image. We can identify the influence of rapid urban development on

Table 1.

Feasibility matrix of marine ecotourism

\begin{tabular}{|c|c|c|c|c|c|c|}
\hline \multirow[t]{2}{*}{ Parameter } & \multirow[t]{2}{*}{ unit } & \multirow[t]{2}{*}{ Score } & \multicolumn{3}{|c|}{ Feasibility Criteria } & \multirow[b]{2}{*}{$N(0)$} \\
\hline & & & S1(5) & $S 2(3)$ & S3(1) & \\
\hline \multicolumn{7}{|c|}{ The 1 st category (70 \%) } \\
\hline Water Visibility & meter & 5 & $>10$ & $>5-10$ & $3-5$ & $<3$ \\
\hline Tourism Object Condition & - & 5 & Very good & Good & Poor & Very Poor \\
\hline $\begin{array}{l}\text { The depth of the tourism } \\
\text { object (If any) }\end{array}$ & meter & 3 & $5-15$ & $\begin{array}{l}>15-20 \\
\&>4-5\end{array}$ & $\begin{array}{l}>20-30 \\
\& 3-4\end{array}$ & $>30 \&<3$ \\
\hline \multicolumn{7}{|c|}{ The 2 nd category $(30 \%)$} \\
\hline Current Speed & $\mathrm{cm} / \mathrm{s}$ & 5 & $0-15$ & $>15-30$ & $>30-50$ & $>50$ \\
\hline $\mathrm{pH}$ & - & 4 & $7-8$ & $\begin{array}{l}6.1-6.9 \& \\
8.1-8.5\end{array}$ & $\begin{array}{l}5.1-6 \& \\
8.6-9\end{array}$ & $<5 \&>9$ \\
\hline Salinity & o/oo & 4 & $33-34$ & $\begin{array}{l}31-<33 \& \\
>34-35\end{array}$ & $\begin{array}{l}30-<31 \& \\
>35-36\end{array}$ & $<30 \&>36$ \\
\hline Temperature & $\mathrm{oC}$ & 4 & $26-28$ & $\begin{array}{l}>22-<26 \& \& \\
>28-30\end{array}$ & $\begin{array}{l}18-22 \& \\
>30-33\end{array}$ & $<18 \&>33$ \\
\hline COD & $\mathrm{mg} / \mathrm{L}$ & 2 & $<10$ & $>10-15$ & $>15-25$ & $>25$ \\
\hline
\end{tabular}

Source: (Tanto et al., 2017) \& (Arlius et al., 2017) modified by authors

Table 2 .

FeSupporting parameters for ecotourism

\begin{tabular}{lllllll}
\hline Parameter & unit & Score & \multicolumn{4}{c}{ Feasibility Criteria } \\
& & & S1(5) & S2(3) & S3(1) & N(0) \\
\hline Accessibility & - & 5 & easy & moderate & arduous & Very arduous \\
Land-use conflict & - & 4 & Never & sometimes & often & Very often \\
Security & - & 3 & Safe & Less safe & Very less safe & Not safe \\
The Distance from & - & 1 & Close & Moderately & Far & Very Far \\
City Center & & & & close & & \\
\end{tabular}

Information:

S1 Category : Very feasible with the score of 75-100 \%

S2 Category : Moderately feasible with the score of $50-75 \%$

S3 Category : Conditionally feasible with the score of $25-50 \%$

N Category : Not feasible with the score of $<25 \%$ 
altering the land use in Mandeh Bay from this stage. The local government reported that a lot of resorts had been built along the coastline illegally. Because of the indigenous customary law, government regulation seems unpowerful enough to slay the illegal resort in Mandeh Bay. Thus, we mapped the coastal utilization and potential zone. Those maps consist of spatial coral mapping analyzed using the Lyzenga method (Lubis et al., 2018) and Landsat 8 OLI digitations.

As we mentioned in the introduction, Mandeh Region is prone to coastal hazards. Due to this condition, A survey assessing the vulnerability level in the coastal area of Mandeh is crucial, knowing that Mandeh is a vital area. We used a Smartline method (Sharples et al., 2009), considering several significant parameters determining the vulnerability level as follow:

- Indicative mapping determines the geological condition as a fundamental factor.

- The regional assessment examines the geomorphic integrated beaches to vulnerability variables such as climate conditions, sea waves, tidal range, and vertical tectonic movements.

- Site-specific assessment to identify geological, geomorphic, topographic, oceanographic, and climate factors predisposing the coastal system.

- Social vulnerability and risk assessment to determine the socio-economic condition.

From the analyzed parameters above, we used a scoring method to classify the vulnerability criteria. Score 1 represents the deficient category, and rating 5 represents a very high category. Moreover, we also employed a CVI (Coastal Vulnerability Index) method (Dhiauddin et al., 2019; Gemilang et al., 2020; Gornitz et al., 1992) with the formula as follow:

$$
C V I=\sqrt{\frac{X 1 * X 2 * X 3 * X 4 * \cdots, * X n}{n}}
$$

where,

$\mathrm{x}$ : the score of every parameter assessed,

$\mathrm{n}$ : the number of parameters employed in this study.

\section{RESULTS AND DISCUSSION}

\section{Feasibility of Mandeh Coastal Bay for Ecotourism Interest}

Table 3 shows the result of the feasibility assessment in Mandeh Coastal Bay. Overall, Mandeh bay is sufficiently feasible as the ecotourism center with the S2 category (72.46\%) for all the observed stations. At station 1 (MV Boelongan Netherland shipwreck site), the condition of the tourism object is excellent and accessible for beginner divers, but the visibility is sufficiently turbid during ebb tides. At station 2 (Sironjong Island), the tourism object's condition is quite attractive, which everyone can access. Still, we scored lower because of its fewer visits by the tourist (not properly managed). Sutan Island (station 3) is the most visited island; the attraction of the underwater view is breathtaking. Unfortunately, this island is over-explored, mass tourism commenced to pollute the surrounding area, and the accumulation of marine debris emerged, which is why we score lower for category 2 . The last station is located on Cubadak Island. It is the first island successfully developed by foreign investors. The tourism object condition is quite good and can be accessed by everyone, but the marine debris issue exists in this area because of mass tourism.

To conclude, Mandeh coastal bay is moderately feasible for espousing ecotourism activities. Several problems like mass tourism-induced marine debris accumulation and pollution, the rapid urban development (the presence of many resorts in the coastal area), and many other properties are caused by a lack of regulation to manage the ecotourism area. Limitation of the number of tourist visits is crucial to be implemented so that the pressure of mass tourism to the objects can be diminished.

Like the ecotourism parameters, the assessment of the supporting parameter resulted in moderate feasibility for espousing ecotourism. All sampled areas are easily accessed due to shortcut crossroad PadangMandeh, reducing the distance and travel time. However, the hilly track sometimes becomes an obstacle causing slips and accidents. Water transportation such as a boat for tourists is also available with a travel package or by request. On the other hand, the land-use issue

Table 3.

FeSupporting parameters for ecotourism

\begin{tabular}{|c|c|c|c|c|c|c|}
\hline \multirow{2}{*}{$\begin{array}{l}\text { Ecotourism } \\
\text { Object } \\
\text { Category I (\%) }\end{array}$} & \multicolumn{2}{|c|}{$\begin{array}{l}\text { Shipwreck } \\
\text { site }\end{array}$} & \multicolumn{2}{|c|}{$\begin{array}{l}\text { Sironjong } \\
\text { Island }\end{array}$} & \multirow[t]{2}{*}{$\begin{array}{l}\text { Sutan } \\
\text { Island }\end{array}$} & \multirow[t]{2}{*}{$\begin{array}{l}\text { Cubadak } \\
\text { Island }\end{array}$} \\
\hline & 52.77 & 42 & 52. 97 & 42 & & \\
\hline Category II (\%) & 25.33 & 22.93 & 22.63 & 24.23 & & \\
\hline Feasibility level & S2 & S2 & $\mathrm{S} 2$ & S2 & & \\
\hline \multicolumn{4}{|c|}{ The Average of Feasibility Level (\%) } & 72.46 & & \\
\hline
\end{tabular}


seems like pressure on the environment, as Wisha et al. (2021) reported. In terms of security, to date, no overwhelming criminality issues written by locals.

\section{Marine and Land Debris Issue}

As mentioned in the last sub-section, rapid urban development and mass tourism problems in Mandeh Bay is the increase of tourist waste within the ecotourism area. This issue is crucial because it can hamper the biota survival ability and exacerbate the environmental quality (Alexandrakis et al., 2015).

The existence of many resorts along the coast of Mandeh contributes to induce coastal pollution and damages. Locals reported the regional coral bleaching in Manjuto Beach in 2019 (Wisha et al., 2021). The coral bleaching event uncommonly happened whereby the anomaly in salinity and $\mathrm{pH}$ was identified. It is predicted as a role of the increase in household waste. Several coral habitats were also demised due to the construction of the traditional quay-connected resort and the shortcut railroad connecting Padang City and Pesisir Selatan Regency.
In 2015, a domestic tourist captured a photo showing the severity of waste disposal in the Top View of Mandeh (Figure 1). In that year, the visits to local and overseas tourists reached their peak level (Figure 2). Over five years (2010-2015), the number of visits to Mandeh Bay gradually increased, started to decline in 2016, and tended to elevate in 2017. While in 2018, the number of tourism visits declined significantly, with around $30 \%$ subtraction.

In 2018, one local online news reported that the concentration of marine debris commenced increasing, dominated by plastic debris (Figure 3). This condition indicates that the local accumulation of marine debris resulting from household waste is tremendously alarming. This reality is not only the responsibility of the local and central government but also everybody's responsibility. The increase of marine debris is undoubtedly avoided when the rapid urban development and mass tourism phenomena occur. On the other hand, the role of local government in the form of advanced regulation to curtail the number of tourism visits is necessary. The implementation of

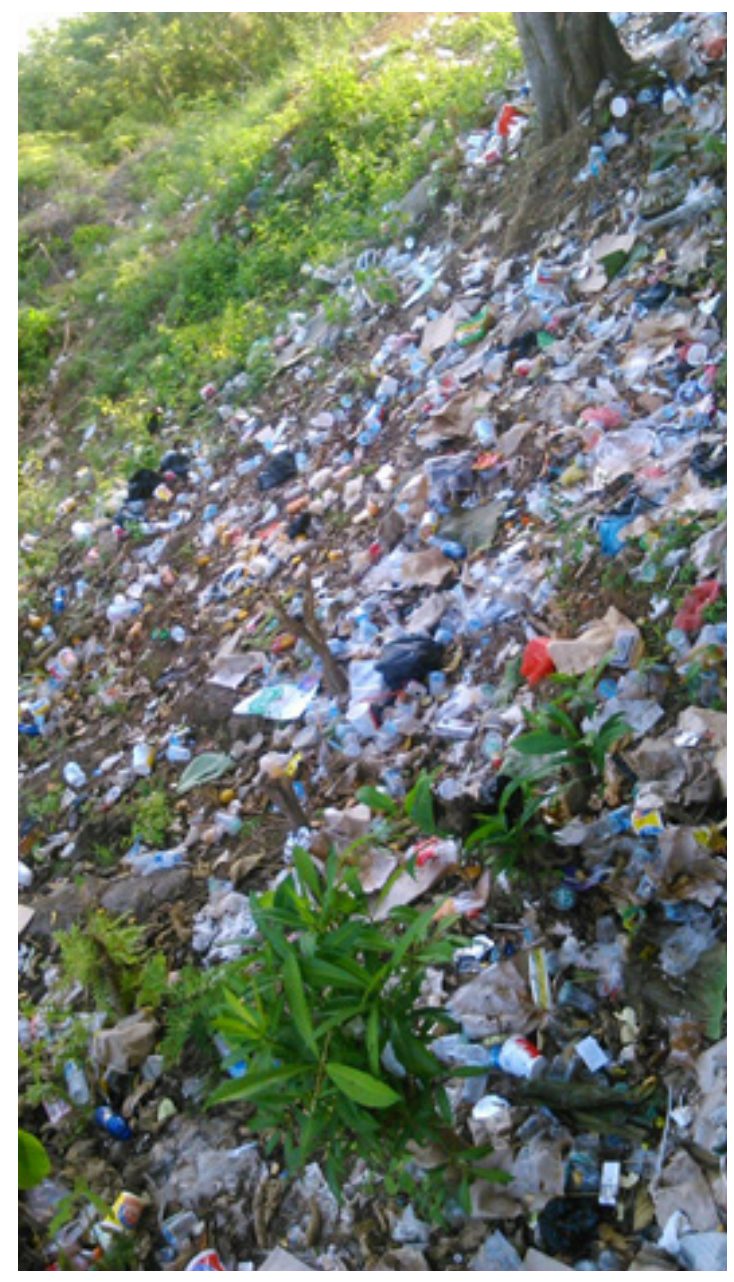

Figure 1. The evidence of tourist debris in the Top View of Mandeh. Source: Courtesy Asep Wijaya, 2015. 


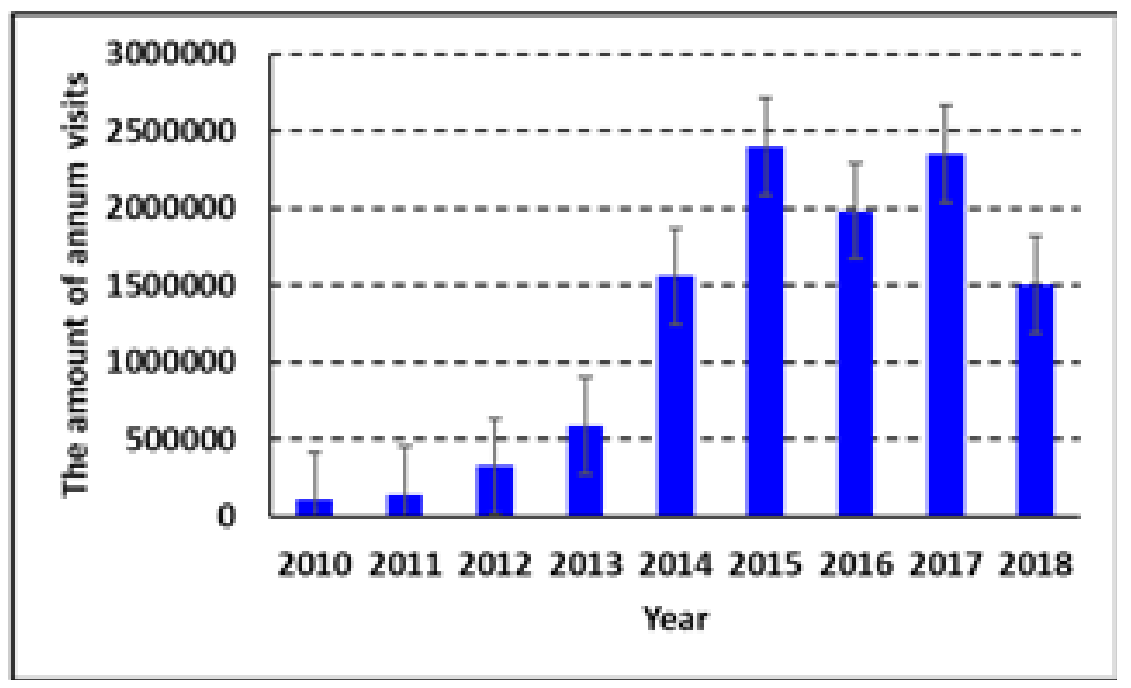

Figure 2. The amount of tourist visits in Mandeh Region.

Source: Department of Tourism, Creative Economy, Youth, and Sports, Pesisir Selatan Regency, 2018.

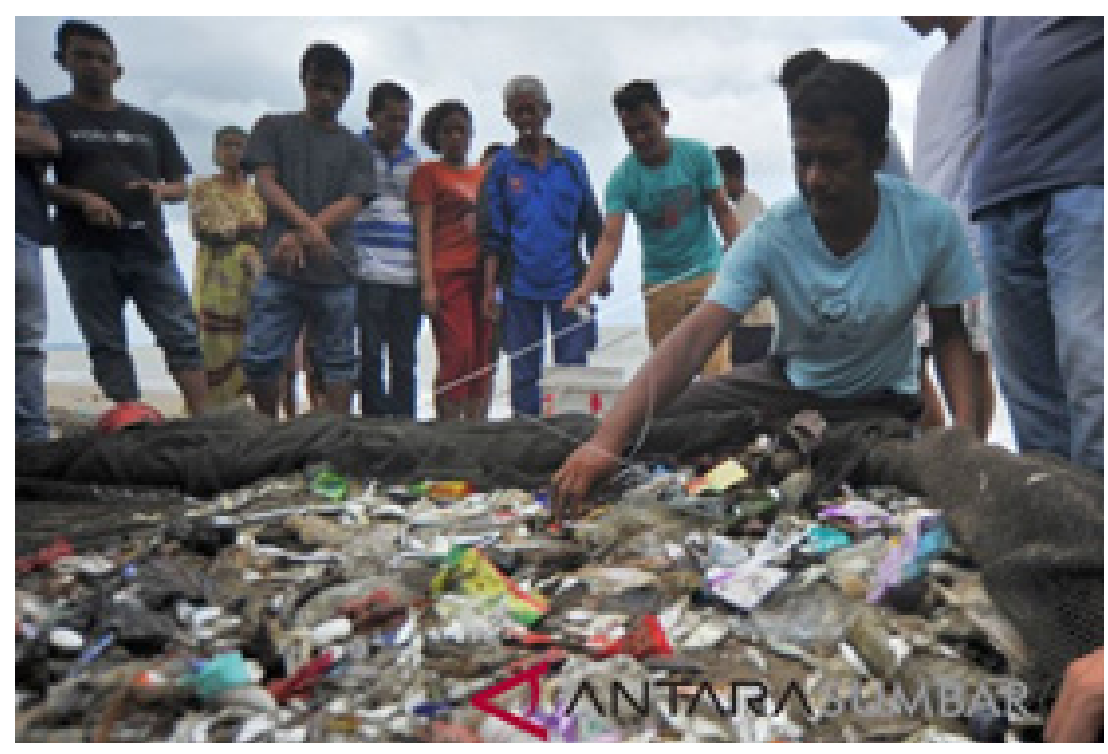

Figure 3. The plastic debris within Mandeh Bay collected by locals.

Source: Courtesy Antara News, 2018

local management is too late, resulting in social and environmental problems.

\section{Local Zonation and Land-use Changes}

We categorized the utilization zone into three main zones: settlement area, aquaculture, and tourism zone (Figure 4). It shows that the land-use change in Mandeh Region is taking place. The opposite condition is found in Cubadak Island, whereby the settlement is not rapidly developed. We can consider that Mandeh Bay is a perfect place for aquaculture because it is a semi-enclosed bay where the ocean dynamics tend to be weak (Rahmawan et al., 2020). Several fish cages were erected within the bay to boost aquaculture productions.

Land-use changes mainly occurred in the Mandeh Village. Moreover, the rapid development took place when the connecting road Padang-Pesisir Selatan was opened for the public. Several points have pinned in Figure 5 shows that many areas had been altered. From Sungai Pinang up to Mandeh Village, there are many new constructions in tourism interests. During the process of development, locals reported that this activity was damaging forests and ecosystems as well.

Besides, the zonation system can divide areas according to its function; it is essential to reduce the 


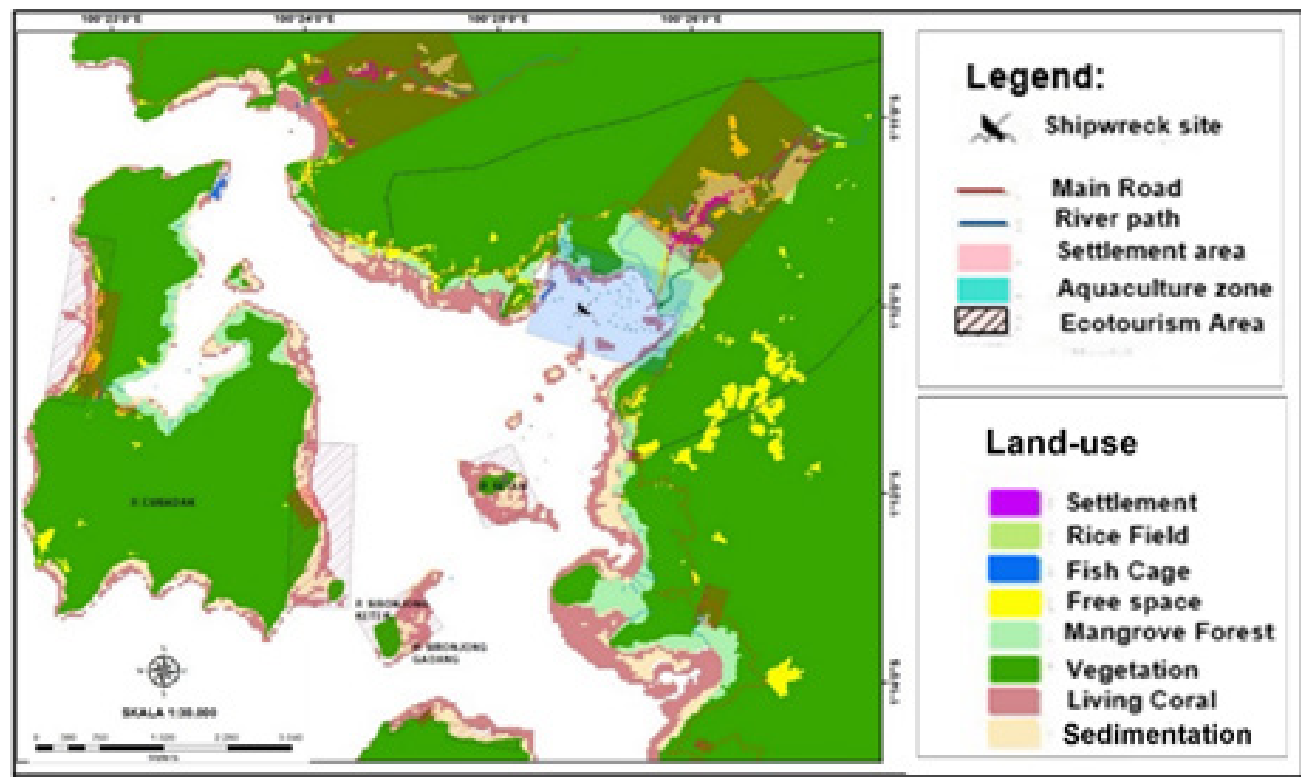

Figure 4. The map of Utilization and Potential Zone within Mandeh Bay

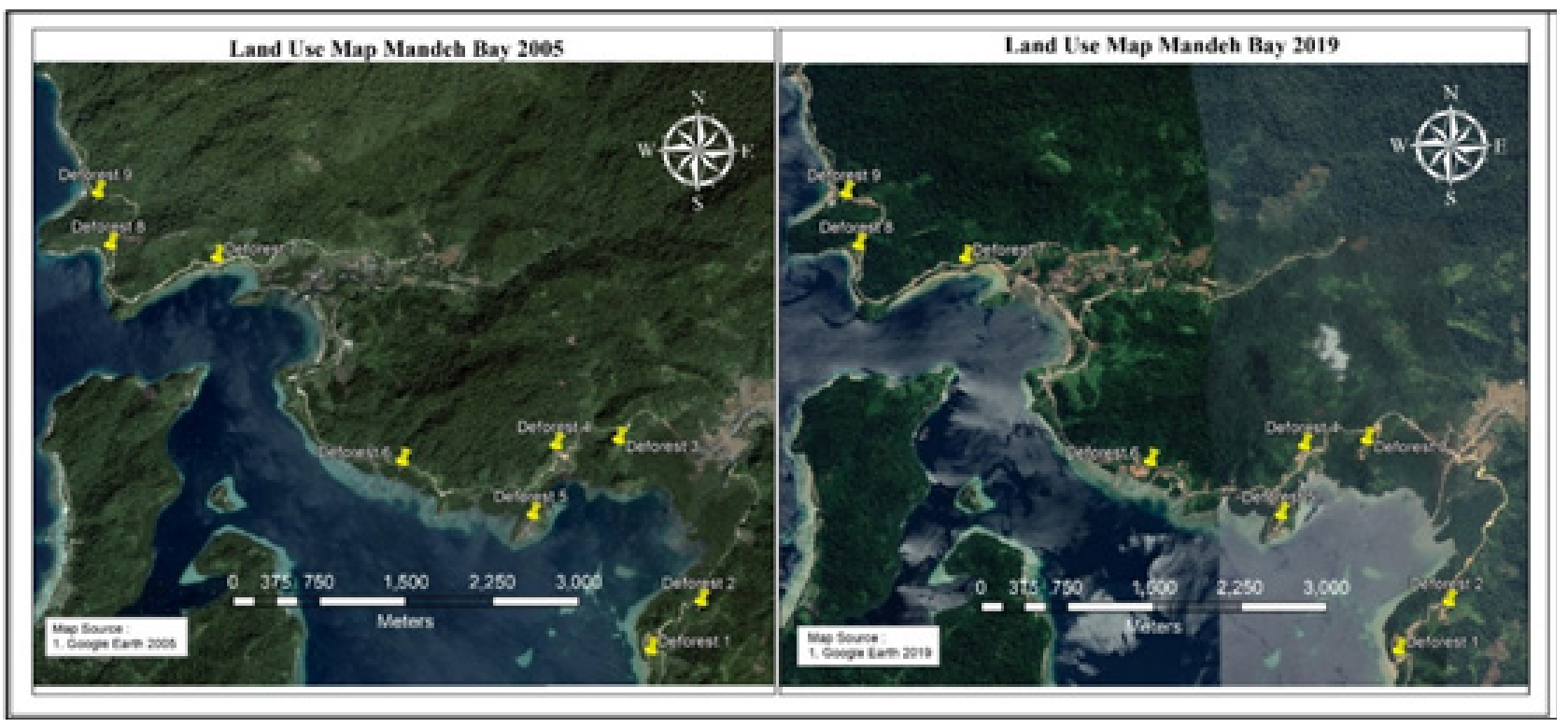

Figure 5. Point of land-use changes over 14 years in Mandeh Region.

pressure on tourism objects and the environment. Regulation and management in local zonation need to be well-implemented in the Mandeh region. The MV Boelongan shipwreck is a fragile underwater object (Dillenia \& Troa, 2016). Successive damages might threaten this site in the form of over-capacity diver diving in the surrounding shipwreck. If the local government cannot manage this underwater heritage, we will not see the whole shipwreck in the future.

The transformation of mangrove forests in Mandeh Bay takes place, resulting in erosion in several sites. The unstable coastal features are caused by the absence of vegetation so that the natural protection in a coastal area is being vanished (van Wesenbeeck et al., 2015). This condition is dangerous for the coastal community. As mentioned above, the Pesisir Selatan Regency is prone to hazards and disasters that might be destructively damaging the settlement and tourism area within Mandeh Bay.

Even though the development in the tourism area is suitable for the investment and economy sector, the significant land-use change in Mandeh Region is believed to induce other new problems such as land disputes, dumping waste accumulation, ecosystem damages, etc.

\section{Coastal Vulnerability Model Assesment}

From the survey assessing some physical 


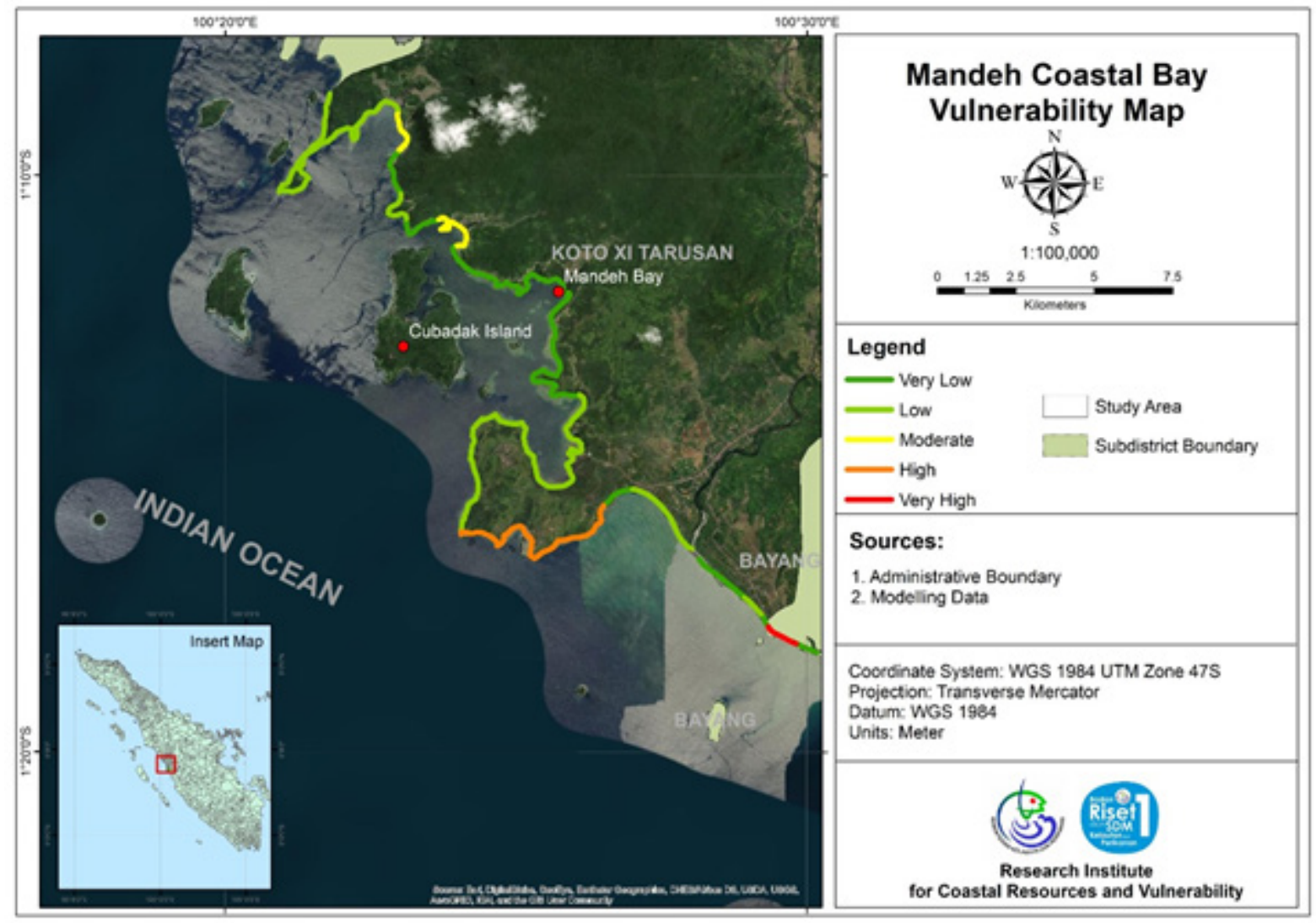

Figure 6. The map of coastal vulnerability level in mandeh Bay.

parameters using the Smartline and CVI model, we can say that Mandeh Bay is quite vulnerable to hazards and disasters. Within the bay, the coastal vulnerability level is deficient due to Cubadak Island's existence in the outer part of Mandeh Bay. This continental formation makes Mandeh Bay become a semi-enclosed protected area. We also gained the coastline changes percentage in Mandeh Region that within the last 12 years, $22 \%$ of Mandeh coastline was experiencing accretion. This condition is caused by the high sediment intake from the Mandeh River due to the rapid urban development in the coastal area. However, approximately $24 \%$ was stable, $47 \%$ underwent lowscale abrasion, and $2 \%$ was the eroded area (Figure 6 ).

Based on CVI calculation, we found that $48 \%$ of the total area of Mandeh Bay is categorized as a shallow vulnerability area. However, some areas are prone to hazards and disasters, with around $16 \%$ and $36 \%$ moderate to low vulnerability. Even though Mandeh Bay is suitable for tourism based on the vulnerability state, excellent coastal management is necessary.

The nowadays issue is the high sedimentation and environmental problems within Mandeh Bay (Syam, 2017). Rapid urban development has contributed to the enhancement of coastal vulnerability. An advanced regulation is crucial to control the mass tourism and over-exploration in Mandeh Coastal Bay. Local people and governments play a critical role in diminishing the impact of developments by which they can manage and protect their natural resources and heritages as a regional asset (Yusnikusumah \& Sulystiawati, 2016).

\section{CONCLUSION}

Mandeh Bay is sufficiently feasible for espousing marine ecotourism activities. Mass tourism and rapid urban development have a significant role in environmental degradation, causing the accumulation of marine and land debris. The increase in visits number contributes to the deteriorating quality of the ecotourism area; many resorts and souvenir stores had been built by damaging the mangrove forest area. Local zonation is essential to limit the pressure to ecotourism areas, thereby declining the social and environmental issues. Land-use changes are likely to reflect the high level of development, which induces the bay's sedimentation issue. Mandeh coastline is categorized to moderate - shallow vulnerable area showing that this region is suitable to be established as the center of marine ecotourism in West Sumatra Province. However, and advanced regulation and coastal management are crucial to diminish the impact of mass tourism and rapid development on social and environmental aspects. 


\section{ACKOWLEDGEMENTS}

Acknowledgment and gratitude are given to Research Institute for Coastal Resources and Vulnerability (RICRV) for the research funding in Pesisir Selatan Regency in 2018 and 2019 and to those who have a role in the completion of this article. The main contributor of this article is Ulung Jantama Wisha.

\section{REFFERENCE}

Alexandrakis, G., Manasakis, C., \& Kampanis, N.A. (2015). Valuating the effects of beach erosion to tourism revenue. A management perspective. Ocean and Coastal Management, 111, 1-11. https://doi.org/10.1016/j.ocecoaman.2015.04.001

Arlius, A., Bulanin, U., \& Mayasari, L. (2017). Study of Tourism Area Feasibility in Angso Duo Coastal Island, Pariaman City, West Sumatera. The 3rd National Seminar on Marine and Fisheries Proceeding of Trunojoyo University, 1-12.

Dhiauddin, R., Gemilang, W. A., Wisha, U. jantama, \& Ondara, K. (2019). Coastal Vulnerability Index Modeling for Western Coast of Pangandaran. Jurnal Segara, 15(2), 109-118. https://doi.org/ http://dx.doi.org/10.15578/segara.v15i2.7001

Dillenia, I., \& Arief Troa, R. (2016). Identifikasi Situs Kapal Karam Bersejarah "Karang Panjang" di Perairan Pulau Laut Natuna. Jurnal Kelautan Nasional, 11(1), 11-20. https://doi.org/10.15578/ jkn.v11i1.6063

Gemilang, W.A., Wisha, U.J., \& Dhiauddin, R. (2020). Coastal Vulnerability Assesment of Tourism Area And Management Srategy for Susstainable Environmental Resilience: Case of Mandeh Coast , West Sumatera. MAJALAH ILMIAH GLOBE, 22(1), 1-12.

Gornitz, V.M., White, T.W., \& Daniels, R.C. (1992). A coastal hazards data base for the US East Coast. Environmental Sciences Division.

Hermon, D. (2016). The Strategic Model of Tsunami Based in Coastal Ecotourism Development at The Strategic Model of Tsunami Based in Coastal Ecotourism Development at Mandeh Regions, West Sumatera. Indonesia. Journal of Environment and Earth Science, 6(4), 4045. https://doi.org/https://doi.org/10.7176/ JEES.2016.001

Holladay, P.J., Dixon, A.W., Nguyen, M.C., Nguyen, B.L, Xu, S., \& Price-Howard, K. (2018). Stakeholder perceptions of tourism assets and sustainable tourism development in da nang, Vietnam. Enlightening Tourism, 8(2), 74-98. https://doi. org/10.33776/et.v8i2.3357

Lubis, M.Z., Anurogo, W., Hanafi, A., Kausarian, H., Taki, H.M., \& Antoni, S. (2018). Distribution of benthic habitat using Landsat-7 Imagery in shallow waters of Sekupang, Batam Island, Indonesia. Biodiversitas, 19(3), 1117-1122. https://doi.org/10.13057/biodiv/d190346

Mukhtar, P.D., Rudiyanti, S., \& Purwanti, F. (2016). Analysis of Tourism Suitability in Nyalo Coast (Mandeh Region) Pesisir Selatan Regency, West Sumatera. Management of Aquatic Resources Journal, 5, 420-426.

Rahmawan, G.A., Wisha, U.J., Gemilang, W. A., Ilham, I., \& Husrin, S. (2020). Prediksi Akumulasi Sedimen Berdasarkan Survei Batimetri dan Hidrodinamika di Pesisir Teluk Mandeh, Kabupaten Pesisir Selatan, Sumatera Barat. Jurnal Kelautan Tropis, 23(1), 105-116. https://doi.org/10.14710/jkt. v23i1.6076

Santoso, E., Widiyantoro, S., \& Sukanta, I.N. (2011). Stusi Hazard Seismik dan Hubungannya dengan Intensitas Seismik di Pulau Sumatera dan Sekitarnya. Jurnal Meteorologi Dan Geofisika, 12(2), 129-136. https://doi.org/10.31172/jmg. v12i 2.93

Sharples, C., Mount, R., \& Pedersen, T. (2009). the Australian Coastal Smartline Geomorphic and Stability Map Version 1: Manual and Data Directory. In October.

Syam, A. (2017). Development Strategy in BioGeophysic Ecological Area of Mandeh Tourism to Meet Asean Economic Community (MEA). Sumatra Journal of Disaster, Geography and Geography Education, 1(1), 50-56. https://doi. org/10.24036/sjdgge.v1i1.35

Tanto, T.Al, Putra, A., \& Yulianda, F. (2017). Ecotourism feasibility in Pasumpahan Island, Padang City. Majalah IImiah Globe, 19(2), 135-146. https://doi. org/10.24895/mig.2017.19-2.606

van Wesenbeeck, B.K., Balke, T., van Eijk, P., Tonneijck, F., Siry, H.Y., Rudianto, M.E., \& Winterwerp, J.C. (2015). Aquaculture induced erosion of tropical coastlines throws coastal communities back into poverty. Ocean and Coastal Management, 116, 466-469. https://doi.org/10.1016/j. ocecoaman.2015.09.004

Wisha, U.J., Ridwan, N.N.H., \& Tanto, T.Al. (2018). The 
Establishment of MV Boelongan Nederland as the Maritim Conservation Area in Pesisir Selatan Regency.

Wisha, U.J., Dhiauddin, R., Rahmawan, G.A., \& Wijaya, Y.J. (2021). Preliminary identification of causes to local coral bleaching event in manjuto beach, pesisir selatan regency, west sumatra: A hydro-oceano-graphic perspective. Jurnal IImiah Perikanan Dan Kelautan, 13(2). https://doi. org/10.20473/jipk.v13i2.25502

Yusnikusumah, T.R., \& Sulystiawati, E. (2016). Evaluation of Ecotourism Management in Tangkahan Ecotourism Region, National Park of Mount Leuser in North Sumatera. Journal of Regional and City Planning, 27(3), 173-189. https://doi.org/10.5614/jrcp.2016.27.3.1 